\title{
Performance of Czech Football Clubs: Malmquist Index Approach
}

\author{
Michal Tomíček ${ }^{1}$; Natalie Pelloneová ${ }^{2}$ \\ Technical University of Liberec, Faculty of Economics, \\ Department of Business Administration and Management, \\ Studentská 1402/2, 46117 Liberec, Czech Republic \\ e-mail: ${ }^{1}$ michal.tomicek@ tul.cz; ${ }^{2}$ natalie.pelloneova@tul.cz
}

\begin{abstract}
Sport has become an important part of our lives in the modern times and sporting sites contribute significantly to the image and texture of modern cities. Regarding the popularity of sport, and football in particular, it has become an important modern place where specific types of economic and social interaction take place. The aim of this article is to propose a method for evaluating the performance of football clubs based on DEA and Malmquist index. Professional Czech football clubs playing in the Czech football competition Fortuna:Liga were selected for empirical analysis. To analyze the relative efficiency of football clubs, BCC and CCR models were employed. The study was conducted on a sample of 20 clubs through 2 inputs and 1 output collected during the 2015/16 - 2019/20 seasons. For some clubs the values of the Malmquist index were calculated. With help of MI it was possible to quantify the total productivity change factor and to decompose it to technological change and technical efficiency change. The results show that Czech football clubs achieved a relatively high level of efficiency in the period monitored and that traditional clubs achieved the highest efficiency score. These results could help club managers improve the performance of their teams.
\end{abstract}

\section{Keywords}

DEA; Sports statistics; Football; Czech professional football clubs; Malmquist index.

\section{Introduction}

Professional sports competitions attract millions of spectators worldwide. Sports activities then expand further and reach other critical economic sectors, such as hospitality, the media, or tourism. One of the world's most important sports competitions is mainly football competitions, which are extremely important for their economic and social activity. In the Czech Republic, professional football clubs are represented by a professional football league called Fortuna:Liga.

16 teams participate in the Czech highest football competition Fortuna:Liga. Historically, the most successful club has been Prague AC Sparta with 36 titles, followed by SK Slavia Prague with 20 titles. In the last five seasons, the Czech leagues have been dominated by the FC Viktoria Plzeň and SK Slavia Praha teams [1]. Only three teams have participated in all 27 years of the independent Czech league (since 1993): AC Sparta Praha, SK Slavia Praha and FC Slovan Liberec [1].

Although football clubs operate within the same legal framework as other companies, they are a particular type of business due to being mainly conditioned by sporting activities. The question, therefore, arises as to how to measure the performance of football clubs. Some studies mainly show a positive relationship between sports and financial performance. In this context, there is a need to recommend football managers' practices that could help clubs achieve both sports and business achievements. In this article, a method of evaluating the 
performance of football clubs based on data envelopment analysis and Malmquist index will be proposed.

\section{$1 \quad$ Literature Review}

In the last few years, a considerable number of papers have been published that determine the economic and managerial efficiency by data envelopment analysis in various sports. Bhat, Sultana and Dar [2] present an extensive study on the application of various models of DEA in baseball, basketball, cricket, cycling, football, golf, handball, and tennis. It is found that DEA identified the sources of inefficiency and provided possible directions for improvement. A summary of selected authors who apply the DEA method in their research follows. EspitiaEscuer and Garcia-Cebrian [3] apply the DEA method and Malmquist indices to the evaluation of the football teams that have participated in the UEFA Champions League. Brosed Lázaro, Espitia-Escuer and Garcia-Cebrian [4] evaluate the performance of Spanish first-division basketball teams, in terms of efficiency. The second aim is to examine the total factor productivity evolution having information from several years. In their article, GarciaCebrian and Espitia-Escuer [5] analyze productivity levels and its components for teams that participated in the UEFA Champions League between 2003 and 2012. A study by Kang [6] measured the relative efficiency and productivity change of Korean professional sports teams using the DEA model and the Malmquist Index for 2006-2009. Jardin [7] evaluate the efficiency of French football clubs from 2004 to 2007 using data envelopment analysis. Then, in his research, studies the dynamics of clubs' performance using the Malmquist index. Barros and Douvis [8] estimate changes in productivity using data envelopment analysis applied to a representative sample of football clubs operating in the two European countries: Portugal and Greece. Barros and Douvis rank the football clubs according to their change in productivity between the 1999/2000 and 2002/2003 seasons, concluding that some clubs experienced productivity growth while others experienced a decrease in productivity. Barros, Assaf and Sá-Earp [9] present a two-stage bootstrapped DEA model to analyze the technical efficiency of Brazilian premier league football clubs for the period 2006-2007.

\section{$2 \quad$ Methodology}

The data used for the purposes of the research come from the official databases of the Czech Fortuna:Liga and are supplemented by private databases of companies from the football environment. The researched period includes the seasons from 2015/16 to 2019/20. The research is divided into the following five steps.

\section{Step 1: Defining the research sample and compiling a list of football clubs to be evaluated.}

The research included a group of 20 football clubs playing in the highest Czech football league called Fortuna:Liga. Information about these clubs was subsequently obtained for the entire selected period. The core is data from InStat [10], which analyzes the performance of athletes and sports teams. They are supplemented by the database of the Transfermarkt.com server [11] and the databases of the Czech Fortuna:Liga [1].

\section{Step 2: Determination of output and input variables.}

Due to the number of DMUs (16 clubs in one season), two input and one output variable were included in the DEA model. For the model with 16 football clubs (DMUs) and three variables included in the efficiency model, the model has sufficient discriminant power. The first input variable is the number of players (hereinafter I1). The second input variable is total squad market value (hereinafter I2). The number of points achieved in the season was chosen as the output variable (hereinafter O1). 


\section{Step 3: Selection and construction of DEA models.}

The central part of this is the research of performance of Czech professional football clubs playing the highest competition Fortuna:Liga, through the method of data envelopment analysis and Malmquist index. Data envelopment analysis (hereinafter DEA) is used as a specialized modelling tool for evaluating the efficiency of a group of comparable decisionmaking units (i.e., football clubs).

In general, DEA models are based on the inputs and outputs of the evaluated units. Further, the efficiency with which the football club can transform its inputs into outputs is compared, i.e. the extent of the outputs the football club can achieve with the number of available inputs [12].

Generally, DEA models can be divided according to the model's orientation into inputoriented, output-oriented, and non-oriented models. Further sorting of DEA models can be done based on the nature of the production process. In this case, a distinction can be made between models based on the assumption of constant returns to scale (CCR model), and models based on the assumption of variable returns to scale (BCC model) [13].

In the presented article, the CCR-I and BCC-I models with input orientation were applied to the obtained data. In the basic input-oriented CCR-I model with the assumption of constant returns to scale, the objective function is maximized under restrictive conditions (1) [12]. In the case of considering variable returns from scale (BCC-I model), it is sufficient to extend the previous model by the condition of convexity [14]. The CCR-I and BCC-I models differ only by valid convexity condition (2).

$$
\begin{gathered}
E_{0}=\min . \theta-\varepsilon\left(\sum_{i=1}^{m} s_{i}^{-}+\sum_{r=1}^{s} s_{r}^{+}\right) \\
\text {s.t. } \sum_{j=1}^{n} \lambda_{j} X_{i j}+s_{i}^{-}=\theta X_{i 0}, i=1, \ldots, m \\
\sum_{j=1}^{n} \lambda_{j} Y_{r j}-s_{i}^{+}=Y_{r 0}, r=1, \ldots, s \\
\lambda_{j}, s_{i}^{-}, s_{i}^{+} \geq 0, j=1, \ldots, n, i=1, \ldots, m, r=1, \ldots, s . \theta \text { unrestricted in sign. } \\
\sum_{j=1}^{n} \lambda_{j}=1
\end{gathered}
$$

In this model, $\lambda_{j}$ are the weights of all DMUs, $s_{i}{ }^{-}$and $s^{+}{ }_{r}$ are slack variables, $\varepsilon>0$ is an infinitesimal constant defined to be smaller than any positive real number and $\theta$ is the efficiency score that expresses the reduction rate of inputs in order for this unit to reach the efficient frontier.

\section{Step 4: Technical efficiency score calculation.}

Technical efficiency and scale efficiency scores were determined for each football club. All necessary calculations were performed using OSDEA-GUI software. The technical efficiency score determined using the CCR-I model is called the overall technical efficiency (hereinafter OTE). In contrast, the score determined using the BCC-I model is called pure technical efficiency (hereinafter PTE). The overall technical efficiency score can, therefore, be divided into the pure technical efficiency score and the scale efficiency score (hereinafter SE), see relation (3). The scale efficiency measures the degree to which a unit can improve its efficiency by changing its size [15].

$$
S E=\frac{O T E}{P T E}
$$




\section{Step 5: Calculation of the Malmquist Index.}

Basic DEA models do not take into account trends or changes in the efficiency of clubs' activities over time. This deficiency is eliminated using the Malmquist Index (hereinafter MI), which evaluates changes in efficiency over time. The MI can be divided into two parts [16]. The first component measures technical efficiency changes (E) and the second component measures technological changes ( $\mathrm{T}$ ) between periods $t$ and $t+1$.

In this article, input-oriented MI was used, which can be expressed by equation (4). Where $x^{t}$ are inputs in period $t, y^{t}$ are outputs in period $t, x^{t+1}$ are inputs in period $t+1, y^{t+1}$ are outputs in period $t+1 . E_{q}$ is the change in the relative efficiency of unit $q$ with respect to other units between periods $t$ and $t+1, T_{q}$ is the change in production possibility frontier as a result of technology development between periods $t$ and $t+1$, or in other words technological change. In this equation, the MI is calculated as the product of $E_{q}$ and $T_{q}$, and it provides several advantages over other indices [16]. Components $E_{q}$ and $T_{q}$ are given by equations (5) and (6).

$$
\begin{gathered}
M I_{q}\left(x^{t+1}, y^{t+1}, x^{t}, y^{t}\right)=E_{q} T_{q} \\
E_{q} \frac{D_{q}^{t+1}\left(x^{t+1}, y^{t+1}\right)}{D_{q}^{t}\left(x^{t}, y^{t}\right)} \\
T_{q}=\sqrt{\frac{D_{q}^{t}\left(x^{t+1}, y^{t+1}\right) D_{q}^{t}\left(x^{t}, y^{t}\right)}{D_{q}^{t+1}\left(x^{t+1}, y^{t+1}\right) D_{q}^{t+1}\left(x^{t}, y^{t}\right)}}
\end{gathered}
$$

For selected clubs and each period, the values of the distance functions and of each component of the MI were determined in the MaxDEA 7 Ultra software environment. Finally, the value of the Malmquist Index was calculated using equation (4). A value of $M I_{q}>1$ indicates an increase in productivity; $M I_{q}=1$ means there has been no productivity change; and $M I_{q}<1$ means a decrease in productivity [17].

\section{$3 \quad$ Results}

This part of the article is devoted to empirical research, where the nonparametric DEA methodology was used. Table 1 shows the resulting efficiency scores for CCR-I model for all clubs examined from all seasons of the Fortuna:Liga. The last row of Table 1 shows the average values of OTE score. The CCR-I model resulted in the identification of up to four efficient clubs in a single season. This means that the size of these clubs is optimal and at the same time, the clubs are able to transform the given inputs into outputs efficiently. 
Tab. 1: OTE score of Czech clubs playing Fortuna:Liga

\begin{tabular}{|l|c|c|c|c|c|c|}
\hline \multirow{2}{*}{ Club } & \multicolumn{5}{c|}{ OTE } & \multirow{2}{*}{ Average } \\
\cline { 2 - 6 } & $\mathbf{2 0 1 5 / 1 6}$ & $\mathbf{2 0 1 6 / 1 7}$ & $\mathbf{2 0 1 7 / 1 8}$ & $\mathbf{2 0 1 8 / 1 9}$ & $\mathbf{2 0 1 9 / 2 0}$ & \\
\hline 1. FC Slovácko & 0.85 & 0.89 & 0.87 & 0.72 & 0.85 & 0.84 \\
\hline 1. FK Pŕ́bram & 0.52 & 0.71 & - & 0.74 & 0.50 & - \\
\hline AC Sparta Praha & 0.69 & 0.63 & 0.55 & 0.66 & 0.62 & 0.63 \\
\hline Bohemians Praha 1905 & 0.64 & 0.76 & 0.85 & 0.82 & 0.76 & 0.77 \\
\hline FC Baník Ostrava & 0.23 & - & 0.71 & 1.00 & 1.00 & - \\
\hline FC Fastav Zlín & 0.69 & 0.99 & 0.58 & 0.85 & 0.54 & 0.73 \\
\hline FC Hradec Králové & - & 0.96 & - & - & - & - \\
\hline FC Slovan Liberec & 0.85 & 0.60 & 0.63 & 0.71 & 0.72 & 0.70 \\
\hline FC Viktoria Plzeň & 1.00 & 0.78 & 1.00 & 1.00 & 1.00 & 0.96 \\
\hline FC Vysočina Jihlava & 0.65 & 0.89 & 0.70 & - & - & - \\
\hline FC Zbrojovka Brno & 1.00 & 0.87 & 0.55 & - & - & - \\
\hline FK Dukla Praha & 0.66 & 0.83 & 0.79 & 0.48 & - & - \\
\hline FK Jablonec & 0.70 & 0.85 & 0.81 & 0.83 & 0.86 & 0.81 \\
\hline FK Mladá Boleslav & 0.87 & 0.84 & 0.46 & 0.54 & 0.61 & 0.66 \\
\hline FK Teplice & 0.51 & 1.00 & 0.60 & 0.63 & 0.67 & 0.68 \\
\hline MFK Karviná & - & 0.89 & 0.80 & 0.56 & 0.44 & - \\
\hline SFC Opava & - & - & - & 1.00 & 0.65 & - \\
\hline SK Dynamo Č. Budějovice & - & - & - & - & 1.00 & - \\
\hline SK Sigma Olomouc & 0.53 & - & 1.00 & 0.68 & 0.73 & \\
\hline SK Slavia Praha & 0.97 & 1.00 & 0.70 & 1.00 & 0.90 & 0.91 \\
\hline Mean & $\mathbf{0 . 7 1}$ & $\mathbf{0 . 8 4}$ & $\mathbf{0 . 7 3}$ & $\mathbf{0 . 7 6}$ & $\mathbf{0 . 7 4}$ & \\
\hline Sara: Own & & & & & & \\
\hline
\end{tabular}

Source: Own

Table 2 shows the resulting efficiency scores for BCC-I model for all clubs examined from all seasons of the Fortuna:Liga. The last row of Table 2 shows the average values of PTE score. The BCC-I model resulted in the identification of up to six efficient clubs in a single season. This means that the clubs are able to transform the given inputs into outputs efficiently. 
Tab. 2: PTE score of Czech clubs playing Fortuna:Liga

\begin{tabular}{|l|c|c|c|c|c|c|}
\hline \multirow{2}{*}{ Club } & \multicolumn{5}{c|}{ PTE } & \multirow{2}{*}{ Average } \\
\cline { 2 - 7 } & $\mathbf{2 0 1 5 / 1 6}$ & $\mathbf{2 0 1 6 / 1 7}$ & $\mathbf{2 0 1 7 / 1 8}$ & $\mathbf{2 0 1 8 / 1 9}$ & $\mathbf{2 0 1 9 / 2 0}$ & \\
\hline 1. FC Slovácko & 0.99 & 0.92 & 1.00 & 0.80 & 0.88 & 0.92 \\
\hline 1. FK Př́bram & 0.85 & 0.90 & - & 0.81 & 0.84 & - \\
\hline AC Sparta Praha & 0.74 & 0.73 & 0.66 & 0.67 & 0.82 & 0.72 \\
\hline Bohemians Praha 1905 & 0.80 & 0.88 & 1.00 & 0.84 & 0.79 & 0.86 \\
\hline FC Baník Ostrava & 0.76 & - & 0.81 & 1.00 & 1.00 & - \\
\hline FC Fastav Zlín & 1.00 & 1.00 & 0.84 & 0.86 & 0.84 & 0.91 \\
\hline FC Hradec Králové & - & 1.00 & - & - & - & - \\
\hline FC Slovan Liberec & 0.88 & 0.70 & 0.75 & 0.77 & 0.76 & 0.77 \\
\hline FC Viktoria Plzeň & 1.00 & 0.83 & 1.00 & 1.00 & 1.00 & 0.97 \\
\hline FC Vysočina Jihlava & 0.97 & 0.93 & 0.83 & - & - & - \\
\hline FC Zbrojovka Brno & 1.00 & 0.91 & 0.81 & - & - & - \\
\hline FK Dukla Praha & 0.86 & 0.84 & 0.91 & 0.79 & - & - \\
\hline FK Jablonec & 0.86 & 0.97 & 0.81 & 0.83 & 1.00 & 0.89 \\
\hline FK Mladá Boleslav & 0.95 & 0.87 & 0.64 & 0.59 & 0.74 & 0.76 \\
\hline FK Teplice & 0.75 & 1.00 & 0.78 & 0.76 & 0.92 & 0.84 \\
\hline MFK Karviná & - & 0.91 & 0.95 & 0.65 & 0.69 & - \\
\hline SFC Opava & - & - & - & 1.00 & 1.00 & - \\
\hline SK Dynamo Č. Budějovice & - & - & - & - & 1.00 & - \\
\hline SK Sigma Olomouc & 0.87 & - & 1.00 & 0.77 & 0.89 & - \\
\hline SK Slavia Praha & 1.00 & 1.00 & 0.76 & 1.00 & 1.00 & 0.95 \\
\hline Mean & $\mathbf{0 . 8 9}$ & $\mathbf{0 . 9 0}$ & $\mathbf{0 . 8 5}$ & $\mathbf{0 . 8 2}$ & $\mathbf{0 . 8 9}$ & \\
\hline Source: Orn & & & & & & \\
\hline
\end{tabular}

Source: Own

Table 2 also shows that all clubs that were classified as efficient according to the CCR-I model are also classified as efficient according to the BCC-I model. It is apparent that the PTE score in the BCC-I model is higher than the OTE score in the CCR-I model, as the CCRI model considers the scale efficiency (SE), which reduces the OTE value. For clubs that are classified as inefficient according to the CCR-I model yet as efficient according to the BCC-I model, it can be concluded that their technical inefficiency is caused by scale inefficiency. Therefore, it can be stated that the size of these clubs is not optimal and an inappropriate sports tactic was chosen. Scale efficiency and scale inefficiency is shown in Table 3. 
Tab. 3: Scale efficiency of Czech clubs playing Fortuna:Liga

\begin{tabular}{|l|c|c|c|c|c|c|}
\hline \multirow{2}{*}{ Club } & \multicolumn{5}{|c|}{ SE } & \multirow{2}{*}{ Average } \\
\cline { 2 - 6 } & $\mathbf{2 0 1 5 / 1 6}$ & $\mathbf{2 0 1 6 / 1 7}$ & $\mathbf{2 0 1 7 / 1 8}$ & $\mathbf{2 0 1 8 / 1 9}$ & $\mathbf{2 0 1 9 / 2 0}$ & \\
\hline 1. FC Slovácko & 0.86 & 0.97 & 0.87 & 0.89 & 0.97 & 0.91 \\
\hline 1. FK Pŕ́bram & 0.60 & 0.78 & - & 0.91 & 0.59 & - \\
\hline AC Sparta Praha & 0.93 & 0.86 & 0.84 & 0.98 & 0.76 & 0.87 \\
\hline Bohemians Praha 1905 & 0.80 & 0.86 & 0.85 & 0.98 & 0.96 & 0.89 \\
\hline FC Baník Ostrava & 0.30 & - & 0.87 & 1.00 & 1.00 & - \\
\hline FC Fastav Zlín & 0.69 & 0.99 & 0.69 & 0.99 & 0.64 & 0.80 \\
\hline FC Hradec Králové & - & 0.96 & - & - & - & - \\
\hline FC Slovan Liberec & 0.96 & 0.85 & 0.83 & 0.92 & 0.95 & 0.90 \\
\hline FC Viktoria Plzeň & 1.00 & 0,94 & 1.00 & 1.00 & 1.00 & 0.99 \\
\hline FC Vysočina Jihlava & 0.67 & 0.96 & 0.85 & - & - & - \\
\hline FC Zbrojovka Brno & 1.00 & 0.95 & 0.68 & - & - & - \\
\hline FK Dukla Praha & 0.76 & 0.99 & 0.86 & 0.61 & - & - \\
\hline FK Jablonec & 0.81 & 0.88 & 1.00 & 1.00 & 0.86 & 0.91 \\
\hline FK Mladá Boleslav & 0.91 & 0,96 & 0.72 & 0.91 & 0.82 & 0.86 \\
\hline FK Teplice & 0.68 & 1.00 & 0.76 & 0.83 & 0.72 & 0.80 \\
\hline MFK Karviná & - & 0.98 & 0.83 & 0.86 & 0.65 & - \\
\hline SFC Opava & - & - & - & 1.00 & 0.65 & - \\
\hline SK Dynamo Č. Budějovice & - & - & - & - & 1.00 & - \\
\hline SK Sigma Olomouc & 0.61 & - & 1.00 & 0.89 & 0.82 & - \\
\hline SK Slavia Praha & 0.97 & 1.00 & 0.92 & 1.00 & 0.90 & 0.96 \\
\hline Mean & $\mathbf{0 . 7 8}$ & $\mathbf{0 . 9 3}$ & $\mathbf{0 . 8 5}$ & $\mathbf{0 . 9 2}$ & $\mathbf{0 . 8 3}$ & \\
\hline Sara: Own & & & & & & \\
\hline
\end{tabular}

Source: Own

To establish the productivity levels attained by Fortuna:Liga clubs, an additional study using Malmquist index was carried out to improve understanding of empirical implications of productivity measures in professional football. The sample was reduced to the 10 clubs that participated in the Fortuna:Liga in all five seasons.

The change in productivity and its two components were calculated for the clubs that participated in the Fortuna:Liga in the seasons 2015/2016 and 2019/2020, as if they had been consecutive years, with the objective of approximating the evolution of their productivity over the entire period analyzed in this article. The results are shown in Table 4. 
Tab. 4: Malmquist index for the clubs participating in the Fortuna:Liga in the period analyzed

\begin{tabular}{|l|c|c|c|}
\hline $\mathbf{2 0 1 5 / 2 0 1 6}-\mathbf{2 0 1 9 / 2 0 2 0}$ & Efficiency change & Technological change & Malmquist index \\
\hline AC Sparta Praha & 1.028 & 0.941 & 0.968 \\
\hline Bohemians Praha 1905 & 1.030 & 0.991 & 1.021 \\
\hline FC Fastav Zlin & 0.983 & 0.930 & 0.914 \\
\hline FC Slovacko & 1.000 & 0.951 & 0.951 \\
\hline FC Slovan Liberec & 0.971 & 0.932 & 0.905 \\
\hline FC Viktoria Plzen & 1.000 & 0.904 & 0.904 \\
\hline FK Jablonec & 1.038 & 0.964 & 1.000 \\
\hline FK Mlada Boleslav & 0.955 & 0.910 & 0.869 \\
\hline FK Teplice & 1.073 & 0.926 & 0.993 \\
\hline SK Slavia Praha & 1.000 & 0.911 & 0.911 \\
\hline Average & $\mathbf{1 . 0 0 8}$ & $\mathbf{0 . 9 3 6}$ & $\mathbf{0 . 9 4 4}$ \\
\hline
\end{tabular}

Source: Own

On average, the results show a decrease in productivity, an increase in efficiency and technological regression. If the results are interpreted individually for each team, only Bohemians Praha 1905 increases its productivity, due to an increase in efficiency that compensates for its technological regression. On the other hand, FK Jablonec experiences no change in productivity, increase in efficiency and show technological regression.

The rest of the teams show a decline in productivity, some of them due to a drop in both efficiency and technological regression (FK Mlada Boleslav, FC Slovan Liberec, and FC Fastav Zlin). Analyzing the information in Table 4, one could conclude that over the period studied there is a widespread decline in productivity, which is also evident in its two components, but primarily in a technical regression.

\section{Conclusion}

Given football clubs' current economic and financial situation, there is an increasing need to know how efficiently a club uses its resources. In addition, this analysis is also crucial for evaluating the sports performance of clubs. Among the various tools that are widely used to measure efficiency, the data envelopment analysis and Malmquist index were chosen in this article.

In this article, the DEA was applied to the best clubs in the Czech Republic, which participate in the highest football competition Fortuna:Liga. There were 20 different clubs that played Fortuna:Liga in five seasons (2015/16 to 2019/20). The research provided several conclusions.

The first conclusion: from the analyzed period from the point of view of the OTE score, the winner of Fortuna:Liga was always described as efficient with the exception of the 2019/20 season and the club with the lowest OTE score of Fortuna:Liga mostly left the league at the end of the season.

The second conclusion can be drawn from the larger number of seasons included in the research. As can be seen, in the five seasons analyzed, no club was able to maintain efficiency throughout the period under review. It is important to note that the clubs and resources used change from season to season, as do the opponent's teams. Therefore, when an efficient club uses the same resources in the same way in past seasons, it is not enough to be efficient in the coming seasons. 
As a third conclusion, various sources of inefficiency were identified. The first source of inefficiency is observed in pure technical efficiency (PTE) and is related to the waste of inputs. To achieve the same output, a lower value of inputs (i.e., a lower total squad market value or a lower number of players) should suffice. The second source of inefficiency can be observed by calculating scale efficiency and is associated with the selection of inappropriate sports tactics. In this case, of course, the team's head coach is the most involved. The problem is not just how they use their sports resources. These clubs should seek to develop a mediumand long-term strategy to develop new and different tactics with the resources they have or could have in the future. The purchase of players should also take place in the context of the development of these new sports tactics. There are also clubs that suffer from both sources of inefficiency. In this case, clubs should reduce resources and, in terms of size, find out how effective clubs are developing sports tactics.

In this article, changes in productivity in football clubs playing in Fortuna:Liga from 2015/2016 to 2019/2020 have been calculated by means of the Malmquist index. The results obtained in this article show no clear increase in productivity during the period studied, both on the average and individually. In conclusion, it does not appear that the organizer of this tournament has been able to increase the productivity of the teams that has participated in it during the period analyzed. Consequently, the overall recommendation for the football clubs analyzed in this study would be to improve their productivity. Breaking down the Malmquist index into efficiency change and technical change and seeing that neither of the two show a clear increase. Therefore, the recommendation would be to design rules for the tournament that would improve the productivity of the participating teams by linking sports success to the increase in productivity.

\section{Literature}

[1] FORTUNA:LIGA: Statistiky. [online]. 2021. [accessed 2021-02-15]. Available from WWW: https://www.fortunaliga.cz/statistiky?unit=1\&-parameter=1

[2] BHAT, Z. U. H.; SULTANA, D.; DAR, Q. F.: A comprehensive review of data envelopment analysis (DEA) in sports. Journal of Sports Economics \& Management. 2019, Vol. 9, Issue 2, pp. 82-109. ISSN: 2340-7425.

[3] ESPITIA-ESCUER, M.; GARCÍA-CEBRIÁN, L. I.: Productivity and Competitiveness: The Case of Football Temas Playing in the UEFA Champions League. Athens Journal of Sports. DOI: 10.30958/ajspo.3-1-3

[4] LÁZARO, M. B.; ESPITIA-ESCUER, M.; GARCÍA-CEBRIÁN, L. I.: Productivity in professional Spanish basketball. Sport, Business and Management. DOI: 10.1108/SBM07-2013-0024

[5] GARCÍA-CEBRIÁN, L., I.; ESPITIA-ESCUER, M.: Technical progress and efficiency changes in football teams participating in the UEFA Champions League. Fórum Empresarial. 2015, Vol 20, Issue 1, pp. 1-27. ISSN: 2475-8752

[6] KANG, H.-J.: Productivity Change and Relative Efficiency of Professional Sport Teams. The Journal of the Korea Contents Association. 2010, Vol. 10, Issue 10,

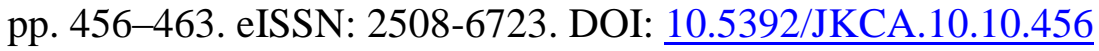

[7] JARDIN, M.: Efficiency of French football clubs and its dynamics. [online]. Munich: Personal RePEc Archive. 2009. [accessed 2021-10-01]. Available from WWW: https://mpra.ub.uni-muenchen.de/19828/1/MPRA_paper_19828.pdf 
[8] BARROS, C. P.; DOUVIS, J.: Comparative analysis of football efficiency among two small European countries: Portugal and Greece. International Journal of Sport Management and Marketing. DOI: 10.1504/IJSMM.2009.028801

[9] BARROS, C. P.; ASSAF, A.; SÁ-EARP, F.: Brazilian Football League Technical Efficiency: A Simar and Wilson Approach. Journal of Sports Economics. DOI: $\underline{10.1177 / 1527002509357530}$

[10] INSTAT: Football. [online]. 2020. [accessed 2021-01-02]. Available from WWW: https://instatsport.com/football

[11] TRANSFERMARKT: Start at Transfermarkt. [online]. 2021. [accessed 2021-01-02]. Available from WWW: https://www.transfermarkt.com/intern/stellenangebote

[12] JABLONSKÝ, J.; DLOUHÝ, M.: Modely hodnocení efektivnosti produkčnich jednotek. Professional Publishing, Prague, 2004. ISBN 978-80-8641-949-7.

[13] COOPER, W. W., et al.: Handbook on Data Envelopment Analysis. Springer Science and Business Media, New York, 2011. ISBN 978-1-4419-6151-8.

[14] SUBHASH, C. R.: Data Envelopment Analysis: Theory and Techniques for Economics and Operations Research. Cambridge University Press, Cambridge, 2004. ISBN 9780521802567.

[15] ZHU, J.: Quantitative Models for Performance Evaluation and Benchmarking: Data Envelopment Analysis with Spreadsheets. Springer, Cham, 2014. ISBN 978-3-31906647-9.

[16] PALEČKOVÁ, I.: Application of Window Malmquist Index for Examination of Efficiency Change of Czech Commercial Banks. DANUBE: Law and Economics Review. DOI: 10.1515/danb-2017-0012

[17] CAVES, D. W.; CHRISTENSEN, L. R.; DIEWERT, W. E.: The economic theory of index numbers and the measurement of input, output, and productivity. Econometrica. DOI: $\underline{10.2307 / 1913388}$

Ing. Michal Tomíček; Ing. Natalie Pelloneová, Ph.D. 


\section{VYUŽITÍ MALMQUISTOVA INDEXU PRO HODNOCENÍ VÝKONNOSTI ČESKÝCH}

FOTBALOVÝCH KLUBÜ

Sport je důležitou součástí našich životů a také velice významně přispívá $\mathrm{k}$ identitě a struktuře moderních měst. Pokud jde o popularitu sportu, zejména fotbalu, stal se významným moderním prvkem, kde se odehrávají specifické druhy ekonomické i sociální interakce. Cílem tohoto článku je navrhnout způsob hodnocení výkonnosti fotbalových klubů na základě metody DEA a Malmquistova indexu. Pro empirickou analýzu byly vybrány profesionální české fotbalové kluby hrající nejvyšší fotbalovou soutěž s názvem Fotuna:Liga. K analýze relativní účinnosti klubů byl použit BCC a CCR model. Studie byla provedena na vzorku 20 klubů hrajících v sezónách 2015/16 - 2019/20. Do modelů byly zahrnuty 2 vstupní proměnné a jedna výstupní proměnná. Pro vybrané kluby byly následně vypočíány hodnoty Malmquistova indexu. Pomocí Malmquistova indexu bylo následně možné kvantifikovat celkovou změnu produktivity faktorů a rozložit ji na technologickou změnu a změnu technické účinnosti. Výsledky ukazují, že české fotbalové kluby dosáhly ve sledovaném období relativně vysoké úrovně efektivity a že nejvyššího skóre efektivity dosáhly tradiční kluby. Tyto výsledky by následně mohly manažerům klubů pomoci zlepšit výkonnost jejich týmů.

\section{LEISTUNG DER TSCHECHISCHEN FUSSBALLVEREINS: MALMQUIST INDEX-ANSATZ}

Sport ist in der Neuzeit zu einem wichtigen Bestandteil unseres Lebens geworden und Sportstätten tragen wesentlich zum Image und zur Struktur moderner Städte bei. In Bezug auf die Popularität des Sports, insbesondere des Fußballs, ist er zu einem wichtigen modernen Ort geworden, an dem bestimmte Arten von wirtschaftlicher und sozialer Interaktion stattfinden. Ziel dieser Arbeit ist es, eine Methode zur Bewertung der Leistung von Fußballvereinen auf der Grundlage des DEA- und Malmquist-Index vorzuschlagen. Für die empirische Analyse wurden professionelle tschechische Fußballvereine ausgewählt, die im tschechischen Fußballwettbewerb Fotuna:Liga spielen. Um die relative Effizienz von Fußballvereinen zu analysieren, wurden BCC- und CCR-Modelle verwendet. Die Studie wurde an einer Stichprobe von 20 Klubs durch 2 Inputs und 1 Output durchgeführt, die in den Spielzeiten 2015/16 - 2019/20 gesammelt wurden. Für einige Vereine wurden die Werte des Malmquist-Index berechnet. Mit Hilfe des MI war es möglich, die totale Faktorproduktivitätsänderung zu quantifizieren und in technologischen Wandel und technischen Effizienzwandel zu zerlegen. Die Ergebnisse zeigen, dass tschechische Fußballvereine im Beobachtungszeitraum ein relativ hohes Effizienzniveau erreichten und traditionelle Vereine die höchste Effizienzbewertung erzielten. Diese Ergebnisse könnten Clubmanagern helfen, die Leistung ihrer Teams zu verbessern.

\section{WYKORZYSTANIE WSPÓŁCZYNNIKA MALMQUISTA DO OCENY WYDAJNOŚCI CZESKICH KLUBÓW PIŁKI NOŻNEJ}

Sport jest ważną częścią naszego życia a ponadto w znaczący sposób przyczynia się do kształtowania tożsamości i struktury nowoczesnych miast. Ze względu na popularność sportu, a w szczególności piłki nożnej, stał się on ważnym współczesnym elementem, w którym zachodzą określone rodzaje interakcji ekonomicznych i społecznych. Celem niniejszego artykułu jest zaproponowanie metody oceny wydajności klubów piłkarskich w oparciu o metodę DEA i współczynnik Malmquista. Do analizy empirycznej wybrano profesjonalne czeskie kluby piłkarskie grające w najwyższych czeskich rozgrywkach Fortuna:Liga. Do analizy względnej efektywności klubów piłkarskich wykorzystano modele BCC i CCR. Badania przeprowadzono na próbie 20 klubów grających w sezonach 2015/16 2019/20. W modelach ujęto 2 wejściowe zmienne i jedną zmienną wyjściową. Dla wybranych klubów obliczono wartości współczynnika Malmquista. Za pomocą współczynnika Malmquista możliwe było skwantyfikowanie ogólnej zmiany produktywności czynników i zdekomponowanie go na zmianę technologiczną i zmianę efektywności technicznej. Wyniki pokazują, że czeskie kluby piłkarskie osiągnęły w badanym okresie stosunkowo wysoki poziom efektywności, a kluby tradycyjne uzyskały najwyższy wynik wydajności. Wyniki te mogą pomóc menedżerom klubów w poprawie wydajności ich zespołów. 